\title{
Service Innovativeness and the Structuring of Organizations: The Moderating Roles of Learning Orientation and Inter-Functional Coordination
}

\begin{abstract}
This paper aims to investigate the influence of organizational structure on service innovativeness by testing the moderating roles of learning orientation and inter-functional coordination. This helps to understand how organic structure influences service innovativeness when it is effectively leveraged with favorable organizational factors. Data was collected from 178 hotel managers and executives in Japan and moderated regression analysis was performed to analyze the data. Findings of the study suggest that higher levels of service innovativeness are positively related to higher levels of hotel business performance. In addition, organic structure makes a positive influence on service innovativeness and an increase in the levels of learning orientation boost the effectiveness of organic structure on service innovativeness. Moreover, the positive association between organic structure and service innovativeness become stronger when all firm's functions make an attempt to cooperate and contribute to disseminating customers and competitors' information in the hotels. These findings contribute to understanding how hotel service innovation is affected by service innovativeness, organizational structure, learning orientation and inter-functional coordination.
\end{abstract}

Keywords: hotel industry, inter-functional coordination, Japan, learning orientation, organic organizational structure, service innovativeness 


\section{INTRODUCTION}

Most service innovation research is based on production-intensive industries, such as financial, telecommunications, transport, and wholesale services (Aas et al., 2015). In contrast, innovation in the hospitality industry such as in hotels and restaurants is rarely studied (Farsani et al., 2016; Randhawa et al., 2015), possibly due to perceptions of their lack of innovation activity (De Jong \& Vermeulen, 2003). Indeed, in the most recent European community innovation survey hotels were the second least innovative businesses after retail industry (Robson \& Achur, 2012). This results from the high turnover and unskilled labor, which hinders hotels from fully exploiting investments in innovative technologies. Hotels often declare themselves too busy or too shortstaffed to innovate (Ottenbacher et al., 2006), or argue that innovation is too costly and not recognizable by customers. However, innovation presents an opportunity for hotels to differentiate themselves from competitors in an industry inundated with similar, often substitutable service offerings.

Innovation can have a positive impact on hotels' firm value, future sales (Nicolau \& SantaMaría, 2013) and competitive advantage (Jacob, 2010) even though these benefits may only be realized at the medium- and long-term level (Campo et al., 2014). In addition, even a small increase in hotel service innovation can have wide implications for the economy considering that the global hospitality industry, of which hotels are a core component, accounts for more than 266 million jobs worldwide (Roth \& Fishbin, 2015). In addition, the industry is growing 23\% faster than the global economy overall by approximately $\$ 3.4$ trillion dollars annually (World Travel and Tourism Council, 2014). It is therefore beneficial both for firm and economic performance to pursue innovations in the hotel sector so empirical research should pursue this relatively unexplored line of study and offer practical guidance on effective ways to innovate. 
Service innovation is a radically or incrementally changed service concept, client interaction channel, service delivery system or technological concept that individually, but most likely in combination, leads to increased value creation for either or both the internal and external customer; and requires the application of specialized competencies (i.e. knowledge and skills) and management of inter-functional coordination (Van ark, 2003). Research by Hirunyawipada and Beyerlein (2010) suggests that service innovation requires the input of multidisciplinary and cross-functional sources of knowledge in order to have performance benefits. According to Ho (2009) and Stonehouse and Pemberton (1999), a conducive environment that facilitates organizational learning comprises of organizational variables such as organic organizational structure and effective inter-functional coordination. Yeh et al. (2006) and Ho (2009) attest that such enablers influence how firms learn and develop, create, share and protect knowledge. In addition, organic structure and effective inter-functional coordination improve the effectiveness of knowledge management related activities, such as empowering individuals to use their knowledge for innovation (Theriou et al., 2011). In particular, supportive flexible organic structures with decentralized organizational architecture are also found to be more capable to respond quickly to changing external environments and have the ability to assimilate and react to information (Altinay \& Altinay, 2006). The rational is that such organizations are effective in producing a great number of creative ideas from an array of multiple groups within an organization (Olson et al., 1995).

Even though these detrimental effects associated with innovation and business outcomes have been empirically scrutinized widely in the manufacturing industry, very little knowledge exists regarding the impact of organizational structure on service innovativeness and the performance of service organizations such as hotels and leisure facilities (Agarwal et al., 2003; Hodari, et al., 
2017; Sin, et al., 2005). More specifically, to our best knowledge, relatively few management academics and scholars have conducted research, in the empirical sense, on the proposition of the adoption and confluences of organic structure along inter-functional coordination and learning orientation on service innovation (Chang et al., 2011; Øgaarda et al., 2008; Tajeddini, 2011).

Given the research gaps above, this research attempts to examine the effect of organization structure on service innovativeness and the subsequent effect of receptivity to new ideas on service performance. In order to address this void in the literature, we empirically examine the moderating role of inter-functional coordination along with the organizational learning orientation on service innovativeness. We build our proposed hypothesized model based on the work of Auh and Menguc (2005) who have articulated the leveraging role of inter-functional coordination in strengthening the effect of organization hotel structure. We begin by discussing the theoretical background, followed by the development of hypotheses. To identify and determine which factors lead to higher service innovativeness, regression analysis was employed to test the interconnections. Results are based on data analyzed from questionnaires received from a sample of over 178 Japanese hotels actively involved in service innovation. We conclude by presenting a discussion of theoretical results and practical implications along with research limitations and directions for future research.

\section{The Hotel Industry in Japan}

The tourism industry is one of the largest sectors in the Japanese economy which contributes to economic growth and job creation (Honma \& Hu, 2012). In 2014, the direct contribution of the tourism industry (e.g., hotels, travel agents, airlines and other passenger transportation services) to the GDP of Japan was JPY11,900.6 bn (2.4\% of GDP) and generated 4,441,500 jobs ( $7.0 \%$ of 
total employment) accounted nearly for $7 \%$ of total employment (OECD Japan Tourism Trends and Policies, 2015). By 2025, it has been forecasted Travel \& Tourism to support 4,857,000 jobs ( $8.0 \%$ of total employment), an increase of $0.5 \%$ pa over the period (OECD Japan Tourism Trends and Policies, 2015).

Despite the number of Japanese-style inns declining, hotels have been growing in scale and number (JETRO, 2009). In particular, we have witnessed that conventional and unconventional hotels particularly around Tokyo have documented a consistent upward trend in average daily rates since 2012 (Sawayanagi et al., 2014). The increasing growth rate of the hotel industry can be attributed to the Japanese governments' programs support of the tourism industry including the launch of a Visit Japan Campaign in 2003 to revitalize tourism and increase the influx of foreign tourists (Honma \& $\mathrm{Hu}, 2012$ ), the enactment of a Basic Act for Promoting a TourismOriented Country in 2007, the establishment of a Japan Tourism Agency in 2008, and the factor of "Abenomics" (i.e., an aggressive set of monetary and fiscal policies, combined with structural reforms) (Sawayanagi et al., 2014). By 2020, Tokyo's hotel pipeline is expected to increase by around $8 \%$ or an additional 7,500 rooms (Sawayanagi et al., 2014). With these efforts, the demand for hotel rooms has increased significantly. For instance, the number of foreign visitors grew from 3.3 million in 1995 to 8.3 million in 2008 , although this number declined to 6.9 in 2009 due to the global economic crisis (JETRO, 2009).

Another remarkable trend that has contributed to the high growth rate of hotels is the surge of foreign-capital hotels, including prominent brand hotels such as Four Seasons, Mandarin Oriental, The Conrad, The Ritz-Carlton and The Peninsula (JETRO, 2009). Nevertheless, hotels in Japan are challenged by the continuing economic downturn, resulting in a downtrend of domestic leisure and business trips (Takeuchi, 2010). However, little knowledge exists about the 
relationship between the hotel structure, learning orientation, inter-functional coordination and their influence on innovativeness and economic service performance. This study stresses the need to provide top hotel managers and executives with more possible course of actions on specific structural elements and entrepreneurial activities influencing hotel innovation and enhancing efficiency and effective hotel performance.

\section{THEORETICAL BACKGROUND AND HYPOTHESES}

\section{Service innovativeness and performance}

Prior research has documented a relationship between non-price factors (e.g., product variation, quality, design, customization, features, innovation, differentiation) and sales growth (Trueman \& Jobber, 1995). Given the importance of differentiation and innovation in the dynamic global market, firms are recommended to be innovative if they want to be competitive in the long term. The innovativeness of a firm can be seen as an openness to new ideas, which is indicated by the ability to develop new products (services/processes), knowledge and technology. Despite the incongruence in the concept of "innovativeness" (e.g. Tajeddini, 2010), a particular common notion reveals that innovativeness can be viewed as "a measure of discontinuity in the status quo in marketing and/or technology factors" (Garcia \& Calantone, 2002, p.118). In recent years, the increasing importance of the value of innovation and innovativeness in the service industry is on the rise. This is due to the nature of service offerings being experiential, which makes service organizations need to constantly innovate in order to enhance consumers' service experiences (Zolfagharian \& Paswan, 2008).

Innovativeness in the service industry embraces a wide spectrum of multiple activities. These activities include supportive leadership, improved services and safety, new technologies, new 
strategy development, communication technologies interaction and a new friendly environment. Service innovativeness along with superior quality is regarded as the key to competitive performance (Johne \& Storey, 1998). Slater and Narver (1995) observe innovativeness in the service industry as a value-creating activity that stimulates market orientation and enhances business performance. Kirca et al. (2005) argue that both customer loyalty and perceived quality of products stimulate innovativeness, which in turn enhances organizational performance. Although some prior research (e.g., Subramanian \& Nilakanta, 1996) found a insignificant association between innovativeness and performance, numerous studies have suggested that greater levels of organizational innovativeness may lead to improved business performance since it increases their capability to cope with the uncertainties generated by a changing environment (e.g., Binder et al., 2016; Brettel et al., 2015; Tsai et al., 2015). Moreover, when controlling different dimensions in organizational culture, Deshpandé et al. (1993) found that innovativeness along with customer orientation is the key for improved organizational performance. Similarly, in their study of Swiss hotels, Tajeddini and Trueman (2012) found a positive relationship between customer orientation, innovation and business performance. Furthermore, in a study of hotel managers in the Alpine hospitality industry, Grissemann et al. (2013) concluded that innovation management and customer orientation are key factors in enhancing the business performance of hotels. We therefore argue that hotels have to develop service innovativeness in order to achieve lower cost and higher quality outputs (Giri \& Tse, 2006; Ottenbacher \& Gnoth, 2005). Thus, the first hypothesis is:

H1: Service innovativeness in hotel firms is positively associated with higher business performance. 


\section{The structuring of organization and service innovativeness}

In contemporary society, which is characterized by a high degree of uncertainty, modern organizations are compelled to respond to continual changes and to view them as potential opportunities if they aim to keep up with growing global market demands and to achieve competitive advantage (Ye et al., 2007). Moreover, management academics along with practitioners perceive that change is omnipresent and can be unpredictably instigated by innovations, internal (e.g., organizational structures, tangible and intangible resources and capabilities, characteristics); and external forces (e.g., competition, customers, government, economy, public opinion) (Ahearne et al., 2010). These dynamic factors induce firms to confront and deal with constant contingencies (e.g. environmental munificence, environmental uncertainty, the state of the economy) that make change pivotal to boost market share and profitability, stay in competition and to sustain their competitive advantages (Liu et al., 2003). Various attempts to examine these factors have resulted in an emergent body of comparative organizational studies dedicated to exploring those characteristics of firms that advance service innovations in internal structures, procedures, inputs, and outputs for value creation (Aiken et al., 1980).

Arguably, general developments and innovations require not only a strategic posture, but also a supportive organizational structure and administrative processes adapting to uncertain environments (Child \& Tse, 2001). The rationale is that organizations are not islands but are linked together in patterns of co-operation and affiliation (Richardson, 1972). Structural contingency theory suggests that organizational context involves constraints to which firms in uncertain environments are required to adjust their organizational structures and procedures to 
adapt their resources and capabilities to the changing contingencies (Collis, 1994; Lin \& Germain, 2003). The structure of an organization explains the organization's internal pattern of authority, relationship and communication amongst different administrative units and departments as well as the stream of information and connections through these established lines of authority and communication (Hall \& Saisa, 1980; Thompson, 1965).

Robbins and Judge (2013) theorized that the way in which communications are designed and the form of the coordination (the organization's structure) is considered as a means to support management to attain its goals that derive from the firm's overall strategy. This view may reveal that structure should follow strategy. The structure of an organization may either impede or enhance the implementation of strategic orientations (e.g., brand orientation, innovation orientation, market orientation, learning orientation, entrepreneurial orientation). Moreover, how an organization is structured depends on contingency variables such as strategy, size, technology, and environment (Robbins et al., 2013). This means that each organization pursues a different approach to discover its strategic growth and to draw up a strategic growth plan organizations are required to identify the opportunities, the unmet needs-created by evolving new technology, changing demographic trends and profile of customers- to exploit as well as employ resources and capabilities more profitably. If an organization tends to operate effectively and efficiently, it requires the formulation and implementation of a new strategy followed by a new refashioned structure (Chandler, 1962).

In 1961, Burns and Stalker developed a continuum of organizational structure exhibiting organic informal structure versus mechanistic formal structure to explain the variation of task differentiation, adaptability, communication, hierarchy, and autonomy. The "organic" structure allows more open communication, more adaptability, increased flexibility, less strict task 
differentiation, less clear hierarchy, and a relatively higher degree of autonomy (Jogaratnam \& Tse, 2006). Alternatively, an organic organization tends to be flexible and have few formal rules and tries to be nimble in a dynamic business climate, paring down bureaucratic complexity and focusing on innovation, flexibility, and creativity (Robbins et al., 2013). Therefore, due to the typical structural options of an organic organization-- a loose structure, low formalization and specialization, and decentralization, the tendency of these originations is to formulate and implement innovation strategy towards meaningful and unique innovation achievement.

Freeman and Engel (2007) note that, creativity in the form of invention of the innovation process is more likely to be associated with an organic organization structure. The rationale is that an organic structure, with open communication, flexible in administrative relations, nonbureaucratic structural attributes is broadly defined and relies on less formalized jobs. This enables an organization to be more entrepreneurial in nature, which allows organizations to be innovative and respond to market opportunities and environmental challenges in an effective manner (Burns \& Stalker, 1961; Pattit \& Wilemon, 2005). Covin and Slevin (1988) consider this organic organization structure as a critical part of an entrepreneurial style of leadership. Moreover, the innovative and entrepreneurial enterprises usually consider a competitive salary and benefits package to attract talented individuals and motivate them to come up with innovative ideas and to take calculated risks (Robbins \& Judge, 2013).

In contrast, mechanistic structures, are characterized by a high degree of specialization, formality, vertical communication, impersonality, division of labor, rigidity in administrative relations, centralized authority, low autonomy and strict adherence to bureaucratic values, principles, rules and protocols (Jogaratnam \& Tse, 2006; Robbins et al., 2013). Mechanistic organizations are often viewed as being more established, traditional and hierarchical along with 
having more formal rules and policies, as well as being more tightly controlled in the way business is conducted (Jogaratnam \& Tse, 2006). These organizations usually pursue a costminimizing strategy that tightly controls costs, refrains from incurring unnecessary expenses, and cuts prices in selling a basic product (Robbins \& Judge, 2013) and are said to impede innovation. Lee et al. (2009) note that adopting new services or offering new products to the market in a timely fashion requires organizations to have high information-processing capacities, more flexibility in administrative relations, faster communication and synchronization.

In a study of sustainability innovations of eco-friendly hotels in Taiwan, Horng et al. (2017) found that a supportive decentralized organizational environment will enhance the effect of innovation diffusion on environmental marketing strategy. Confirming this, both Altinay and Altinay (2004) and Burgess (2013) in their study of hotel chains found that decentralized organizational structure helps hotel organizations respond to the changes in the dynamic environment and become more innovative because such an organizational structure has minimal hierarchical levels or structural layers and adopts free-flow communication channels. These attributes encourage entrepreneurial thinking, permit flexibility and rapid decision making and thus make a positive impact on an organization's innovation performance. In particular, empowering employees through a decentralized organizational structure is found to be an important factor stimulating innovation (Grissemann et al., 2013), particularly in relation to the introduction of incremental service innovations, such as a new software versions not accompanied by major technological changes (Ottenbacher \& Harrington, 2010). Thus, we hypothesize:

$\mathbf{H}_{2}$ : The organic organizational structure has a positive impact on the service innovativeness. 


\section{Learning orientation: Moderating effect}

Learning can be conceptualized as the beliefs and values associated with the development of new knowledge, insights, and awareness (see Huber, 1991; Sinkula, 1994). The strategic marketing literature supports the notion that "learning" is one of the critical avenues to facilitate behavioral change for building an enduring competitive advantage in the marketplace (Day, 1994; Sinkula et al., 1997; Slater \& Narver, 1995). One possible reason is that the more an organization is capable of generating, acquiring, and transferring knowledge (Garvin, 1993), the more likely it will be able to modify its behavior to respond to a rapidly evolving dynamic business environment (Davis et al., 2007). Learning orientation has been seen as the organization's values, which affect its tendency toward knowledge creation and implementation (Sinkula et al., 1997). Strategic management scholars view learning orientation as a distinctive type of strategic orientation and managerial philosophy, and define it as the process where knowledge and information is communicated and disseminated across the organization, which orients employees to improve their abilities and skills (Duncan \& Weiss, 1978).

Within the realm of services marketing, Hennig-Thurau and Thurau (2003) see learning orientation as an aspiration of the staff to advance their knowledge, skills and abilities in a steady and continuous way. As a result, employees who have gained new knowledge and expanded new social and technical skills will interact with customers in a more appropriate way (HennigThurau \& Thurau, 2003). Arguably, because service innovativeness is considered to be a continual process toward long term strategies of an organization, it necessitates continuous learning with personal and professional development as well as engaging a team and the workforce in the quest for innovation (Tajeddini, 2011). In their study of 109 hotels operating in Spain, Nieves et al. (2014) found that knowledge-based resources to learn play an instrumental 
role in determining innovation activity in tourist accommodation firms. Continuous learning increases the abilities of employees to learn from the past and enables them to develop the basis for new and emerging strengths. Such ability and information, along with organic structure and participatory management style, allows employees to be more open to discuss and implement new ways of working and cultivate ideas, which eventually may retain and contribute to service innovativeness in hospitality and tourism firms (García-Villaverde et al., 2017). In a study of general managers in 226 hotels in Taiwan, Tang (2016) found that learning through environmental scanning and social influence contribute to the proactive personality of managers and capacity for service innovation as well as service improvement of hotels, indicating that hotel managers with a proactive personality are helpful at implementing innovation. Thus, we hypothesize the following:

H3: The organic organizational structure has a stronger effect on service innovativeness when learning orientation of hotel organizations is high rather than low.

\section{Inter-functional coordination: Moderating effect}

Management scholars note that traditional and typical business unit-level strategies including product distinctiveness, market segment, cost reduction and leadership, and/or new product and service require extensive coordinated internal efforts of different units (internal functional coordination) to achieve corporate goals and objectives (Defee \& Stank, 2005). Within the realm of marketing strategy, academics argue that all organizations' functions should cooperate and contribute to disseminate the customers and competitors' information in order to create greater value for customers and in return to develop a sustainable competitive advantage (Narver \& Slater, 1990). In a similar vein, Lafferty and Hult (2001) argue that anyone in the organization has the responsibility to attempt to create customer value creation. Efforts to coordinate the 
delivery of integrated business resources are associated with customer and competition orientation. Past research shows that the coordination of sales and marketing functions can increase the effectiveness of activities of marketing departments (Rouziès et al., 2005). Interfunctional coordination is defined as the synchronization of communication, information dissemination and other resources along with integration and collaboration of different functional units throughout the organization to generate value for customers and buyers (Javalgi et al., 2014; Wooldridge \& Minsky, 2002).

Acquiring and sharing information between departments, formulating and implementing strategies, and developing business plans are the key aspects of inter-functional coordination (Altinay, 2010; Deng \& Dart, 1994). As a result, greater information is disseminated resulting in a growth in sales and superior market share. In effect, when an organic organization along with less formalized structure, decentralization and reward systems, has been established, the organization will be able to allocate its resources more efficiently towards the provision of various goods and services, as well as increase its innovative capacity to produce and commercialize a flow of new products and services over the long term. In order to achieve these goals and ensure that the marketing efforts implement consistently and in the same direction, the organization's efforts and strategy must develop all the firm's units and departments (Narver \& Slater, 1990). Previous studies (e.g., Tyler \& Gnyawali, 2002) have shown that inter-functional coordination is a structural aspect of an organization that facilitates the progress of sharing information, communication and coordination among different functions.

The coordinated efforts of different departments are important for the process and implementation of organizational change (Kennedy et al., 2003); allowing the functions to implement the right actions in response to customers' and generate superior value for customers 
(Narver \& Slater, 1990). The importance of inter-functional coordination has been investigated in the context of hospitality organizations. In a study of ethnic restaurants, Altinay (2009) found that inter-functional coordination leads to the effective exploitation of market knowledge and can lead to more 'customer driven' innovative service and product ideas. In another study of international hotel chains, Wang and Altinay (2012) found that inter-functional coordination enriches the knowledge flow and idea generation, stimulates creative thinking, and leads to better international expansion performance (Figure 1). Thus, we hypothesize,

H4: The organic organizational structure has a stronger effect on service innovativeness when inter functional coordination is high rather than low

\section{Figure 1}

\section{METHOD}

Sample and Data Collection

The objective of this study is to assess the moderating role of inter-functional coordination and learning orientation and the relationship between organizational structure and service innovativeness. Although a common approach in marketing strategy research is to study organizations in a wide variety of industries in order to provide the potential to generalize findings across numerous industries (Chandy, 2003), this study focuses on a single industry despite it limiting the generalizability of the findings. However, such an approach minimizes significant sample heterogeneity and unveils context, reduces the variability of flexible practices required by the industry's unique competitive and institutional pressures (Celucha et al., 2002; Chandy, 2003). Additionally, for the current study the internal validity is more important than the generalizability of the results (see McKee et al., 1989). The hotel industry is selected to test the hypotheses because it is characterized as a homogenous industry (Borooah, 1999), highly 
global and caters to a standardized consumer need world-wide (Agarwal et al., 2003) and different hotel rates have little impact on hotel operations (Orfila-Sintes \& Mattsson, 2009). Moreover, due to the continuous change in regulations, the destabilizing effects of technological advancement, tourist preferences, economic crisis, globalization, new lodging solutions along with increasing customer demand and growing competitive pressures on today's tourism/hospitality industry, hotel top managers need to maximize business performance and results through offering service innovativeness as well as new service development (Giri \& Tse, 2006; Ottenbacher \& Harrington, 2010).

Due to the potential concern of common-method bias (Campbell \& Fiske, 1959), or the possibility of alternative explanations to the self-reported data such as self-desirability (Jogaratnam \& Tse, 2006), the respondents' perceptions were employed to supply the most accurate assessment of conditions within an enterprise (Lyon et al., 2000). To decrease the risk of common-method bias, or the possibility of alternative explanations of the self-reported data (Jogaratnam \& Tse, 2006), the respondents' perceptions were employed to provide the most precise assessment of conditions within an enterprise (Lyon et al., 2000). Thus, a mail survey questionnaire was utilized to ask key informants for their perceptions of relevant organizational variables and the link with hotel business performance. The initial questionnaire was first developed in English and then was translated into the Japanese language. In an effort to avoid cultural bias and ensure validity and accuracy of the original measures in the Japanese context, the Japanese version was then back-translated into English by two management researchers competent in both English and Japanese languages with extensive research and hospitality experience in the subject area in Japan. The translators then jointly reconciled all alterations and helped us control for vocabulary and syntactical equivalence in our survey. 
The suitability and appropriateness of the Japanese version of the survey questionnaire draft was then pretested by three Japanese management professors in order to identify any ambiguous or irrelevant items ensuring that the questionnaire content and measurement scales were understandable and captured the entire construct domain. Finally, during a series of face-to-face interviews, we pre-tested the questionnaire with twelve hotel managers for face and construct validity and asked them to identify any repetitive, unclear, confusing, or irrelevant items. During the pretest, some owners and managers were interested in knowing about how this study might support them to gain insight in sharpening and improving their managerial effectiveness and skills. We promised to supply them with an executive summary as a major incentive. In addition, we excluded the pre-test distributed and returned questionnaires from the study. To increase the content validity and response reliability, the survey questionnaire encompassed a variety of issues including: questionnaire design, piloting, pre-notification and post-survey follow-up reminders suggested by previous scholars (e.g., Huber \& Power, 1985). The survey responses were mainly collected by CEOs, top managers, and owners of different rated hotels located in Tokyo because of its location as a popular tourist attraction in Japan. Top managers, executives along with hotel owners were targeted as the key respondents because they typically participate in strategic decision for innovation and new service development (Bonner \& Walker, 2004; Tajeddini, 2011; Tsai et al., 2015).

To identify the addresses of the hotels, we used data from Japan Hotel Almanac (2013). A random sampling method was employed because of the psychometric properties of the scales as well as the financial and time constraints of the research. The random sampling frame represented a full list of all-star grade hotels including independent brands, regional brands and international brands, which are highly representative of the entire industry throughout the 
country. This approach is supported by MacInnis (2005) who notes that this sampling method is paramount in marketing and strategy research. Over a period of several months a direct-mail questionnaire involving three waves was sent to the sample of 700 executives (e.g., CEOs, managers and owners) of the hotels in Tokyo. No explicit incentive was provided. One cover letter was used to explain to the firms' CEOs regarding the aim of the study. In many cases, top executives were first contacted by telephone to seek their support and cooperation. Explicit assurance was given that no individual responses would be disclosed by the research team and would not be linked to them individually, nor to their hotels, or services.

We incorporated one dichotomous item $(\mathrm{Yes} / \mathrm{No})$ as a criterion for inclusion in the study indicating whether a hotel has developed a new hospitality service over the past three years. Additionally, one informant competency dimension was incorporated to the survey, which assessed the respondent's knowledge/ information to evaluate the firm's relationships and firm's performance. Finally, a few open-ended questions were included to lead the respondents to think critically about the issues in the study. Numerous telephone calls were made to explain the objective of the research and to examine the possibility of participating in the study. Some selfadministered questionnaires were mailed to the selected hotel, addressing the managing directors together with a covering letter and a return postage paid envelope.

Some data was also collected through personal visits to the hotels. Two hundred and ninety seven respondents returned the survey and from the total mailings, two questionnaires were nondeliverable and thirty-seven questionnaires were ineligible for reasons including: hotel nonparticipation policy in survey, hotel liquidation, and insuffiecent completion of the survey items which have been removed. Eighty respondents stated that their hotels had not had any new service in the last three years. As a result, we received 178 usable survey questionnaires with an 
effective response rate of $25.42 \%$. We made a series of 30 phone calls to respondents to assure key informant quality and their knowledge about the questions. In order to determine whether significant differences existed between early and late respondents (Armstrong and Overton 1977), we compared responses to each variable by $7 \%$ of the first respondents to those obtained from the last 7\%, and the results of independent samples $t$-tests showed no significant differences between these two groups $(p>0.05)$.

\section{Measure}

Multiple-item measures were adopted from extant organizational strategic management literature and complemented with the conceptual and theoretical facets of each construct. To operationalize organization structure, a seven-item likert scale measures organicity (i.e. the extent to which hotels are organized and structured organic versus mechanistic manners (Covin \& Slevin, 1988). The measure of organization structure has primarily been developed by Khandwalla (1977) and subsequently validated by prior management scholars (see for example, Jogaratnam \& Tse, 2006; Naman \& Slevin, 1993). The scale measures the organic-mechanistic orientation of a hotel (Covin \& Slevin, 1988) and emphasizes the flexibility of a firms structure and considers the structure of hotels as a key to competitive advantage (Connor, 2007). The respondents were asked to evaluate the extent to which the operating management philosophy of their hotels favored characteristics of structure (Table 1).

We calculated the average of the ratings assigned to the items to attain an organicity index for each hotel $(\alpha=.87)$. The higher the index of organicity indicates the more organic the hotel structure is (Covin \& Slevin, 1988; Jogaratnam \& Tse, 2006). This study adopts the work of Narver and Slater (1990) for the inter-functional coordination measure with a five-item, five- 
point Likert scale (1-strongly disagree, 5 -strongly agree) $(\alpha=.85)$. Service innovativeness in the hotel industry was assessed with a five-question measure developed by Hurley and Hult (1998). These items indicate hotel manager's opinion about openness and receptivity to creative and new ideas $(\alpha=.85)$. Learning orientation indicates the hotels' values impact and its inclination to pursue new knowledge and challenge the status quo was operationalized using four items adapted from Baker and Sinkula (1999) and Sinkula et al. (1997) $(\alpha=.88)$. Despite some potential respondent bias (Harris, 2001; Henard \& Szymanski, 2001; Ruekert, 1992), the subjective approach using effectiveness and efficiency was used to assess the respective hotel's business performance relative to that of their competitors. While we measure effectiveness in terms of three indices (i.e., market share growth, sales and profit growth), efficiency was evaluated in terms of profitability, return-on-sales, and return-on-investment (Auh \& Menguc, 2005). Each question was phrased so that respondents assessed these facets of hotel performance over the last 3 years relative to their main competitors' (1-much worse than my competitors; 5much better than my competitors) $(\alpha=.86)$.

\section{Control variables}

We developed control variables to detach the impact of other aspects, which underpin the level of hotel creation activities and might influence a hotel's performance. For this research we included type of hotel, size of hotel, age of hotel, ownership of hotel, brand type and respondent hotel experience as control variables. This meant hotel type was a dummy variable such that 1 indicates a hotel above three stars and 0 represents one below three stars. We used the logarithm of the number of employees to prevent skewness as a sign of hotel size. Hotel ownership was examined by a dummy variable to control for possible variations between domestic hotels (coded 
as 0 ) and foreign chain (coded as 1). Hotel age was gauged by the number of years the hotel had been in operation. Brand type was examined as a dummy variable such that 1 indicates an international brand and 0 represents regional brand or independent brand. The years of experience of the respondent was measured as the logarithm of the number of years since the respondent was working with the hotel and the participant's background (0: marketing/sales; 1 : other).

\section{Common method variance}

Despite our best proactive attempts to minimize any potential common method variance $(C M V)$, common method bias might occur because the data of the variables and constructs was collected from the same respondents (Podsakoff et al., 2003). Two procedural remedies to control for potential $C M V$ and one statistical remedy to evaluate this problem were employed (see Chang et al., 2010). In doing so, on the one hand, the scale items were carefully evaluated by defining unfamiliar terms, avoiding vague concepts and double-barreled items. We kept the items simple, specific, and concise, using a mixed order of the questions (ex ante) and on the other hand, in the cover letter it was guaranteed that the respondents' anonymity would be preserved in order to reduce evaluation apprehension (Chang et al., 2010; Tsai \& Yang, 2014). For the statistical

remedy, after the scale purification, we entered all of the questionnaire items into an unrotated factor analysis to verify the number of factors. As a general rule, if a single factor appears from the factor analysis, that result would point out that the data experience a $C M V$ issue. We conducted a Harman one-factor test to determine the common method bias (Podsakoff \& Organ, 1986). Four factors with eigenvalues greater than 1.0 were obtained and these explained $63.29 \%$ of the total variance. Factor 1 accounted for $31.86 \%$ of the variance less than half of the total 
variance, which means that common method bias is unlikely to be a major problem (Podsakoff $\&$ Organ, 1986).

\section{Measurement validity assessment}

We split the constructs into two groups of theoretically associated variables. the exogenous variables, characterized by 'organizational structure', 'learning orientation', and 'inter-functional coordination', and the constructs of 'service innovativeness' and 'business performance'. By means of AMOS, the CFA procedure, covariance matrices, and the maximum likelihood estimation (MLE), these two sets of constructs were included into the theoretical framework depicted in Figure 1. Using these procedures helped us to examine construct convergence within maximum levels, and to prevent a minimal sample size violation suggested by parameter estimate ratios (Bentler \& Chou 1987).

To check the significance of results, we employed two set of statistics suggested by Venkatraman (1989). First, we computed the significance of the factor loadings (z-values $> \pm 1.96$ and $p<0.05$ ), showing the estimated correlation between a specific item and the latent construct it represents. Then, we examined the overall acceptability of the proposed framework in terms of its fit to the data using some common adjunct fit indices along with a $\chi^{2}$ test. We found that $\mathrm{CFI}=$ 0.98 , Delta $2=0.97$, RNI (relative noncentrality index $)=0.98, \chi^{2}$ (Chi-square) $=134.49, \mathrm{df}($ degree of freedom $)=104, p$-value $=0.02$, and RMSEA (root mean square error of approximation $)=0.04$, indicating that the exogenous model resulted in a reasonable fit to the data (Browne \& Cudeck, 1993; Gerbing \& Anderson, 1992) (Table 1). Similarly, Table 2 displays the fit indices, unidimensionality and convergent validity outcomes of 'hotel service innovativeness' and 'hotel business performance' measures. 


\section{$\underline{\text { Table } 1}$}

$\underline{\text { Table } 2}$

Furthermore, the composite reliabilities $(C R \mathrm{~s})$ for each construct range from 0.71 to 0.90 , which exceed the 0.70 benchmark. The average variances extracted (AVEs) for all constructs are ranged 0.56 to 0.69 higher than the cutoff point. These results reveal that our measures have sufficient convergent validity and reliability. In addition, because exogenous and endogenous models were employed to evaluate the scale properties, we utilized AMOS to run some chi square difference analyses for all constructs in pairs employing the constrained models against the unconstrained models to evaluate discriminant validity between the measures (Bagozzi \& Phillips, 1982; Gerbing \& Anderson, 1987). In doing so, we ran each model twice. The first time, we constrained the phi $(\varphi)$ coefficient to one (unity), next we freed this parameter. The chisquare $\left(\chi^{2}\right)$ difference tests were then carried out on the nested models to examine whether the $\chi^{2}$ values were noteworthy lower for the unconstrained models (Anderson \& Gerbing, 1982). The outcomes indicate that the critical value $\left(\Delta \chi_{1}^{2}>3.84\right)$ was exceeded in all constructs. The results of pairwise (where $U E$ represents the unconstrained estimates and $C E$ represents the constrained estimates) varies from a low $\Delta \chi_{1}^{2}=47.59$ for the combination of learning orientation/ organizational structure constructs $\left(U E_{\mathrm{df}-19}=74.48, C E_{\mathrm{df}-20}=139.50\right)$ to a high $\Delta \chi_{1}^{2}=298.47$ for the combination of the inter-functional coordination/hotel performance constructs $\left(U E_{\mathrm{df}-19}=\right.$ 69.37, $\left.C E_{\mathrm{df}-20}=359.73\right)$.

We also computed the shared variance between all promising couples of constructs based on the correlation results to verify whether they were lower than the average variance extracted for each individual construct. As indicated in Table 3, the shared variances for all possible scales used in the research ranged from a low of $6 \%$ to a high of $29 \%$, along with AVEs ranging between $56 \%$ 
and $69 \%$. The results of AVEs were higher than 0.50 and also considerably higher than its relevant highest shared variance showing discriminant validity between all scales (Bagozzi \& Yi, 1988; Fornell \& Larker, 1981). Table 3 provides the means, standard deviations, and correlations of the constructs of the study.

$\underline{\text { Table } 3}$

\section{Analysis and results}

We performed moderated regressions to analyze the data and to verify the hypotheses. Moderated regressions were conducted because our model contains interactive relationships. Two separate series of three regression models were carried out to assess the possible change in the amount of variance explained $\left(\Delta R^{2}\right)$ to examine the interaction effects and to observe the statistical significance of both overall and incremental $F$ values (Cohen et al., 2003). An application of the procedure suggested by Belsley et al. (1980) indicated that some of our regression coefficients might be affected by multicollinearity. In order to mitigate the potential threats of this issue, after the mean-centering technique, the condition index $(C I)$ and the variance inflation factor $(V I F)$ tests have been made. First, inclusion of the interaction term in the model increased the condition index (i.e., the square root of the ratio of the largest eigenvalue to each individual eigenvalue) to 16.17 from 12.86 . Thus the $C I \mathrm{~s}(<21: 993)$ are well below the critical values suggested by Hair et al. (2010) and also much lower than the value of 30 proposed by Belsley et al. (2004).

The second was the variance inflation factor $(V I F)$. We found that the maximum value in the data was 1.146 , lower than the maximum value of 3 and well below the recommended critical limit (<2:448) (see Hair et al., 2010). According to these results, multicollinearity was concluded to have no substantive impact on the mean-centered regression coefficients. 
Additionally, to assess the explanatory power of each set of variables, we first regressed performance and service innovativeness orientation against the control variables only in the first step in Model 1 and Model 4 respectively; then subsequently added organizational structure and the moderating variables (i.e., inter functional coordination, learning orientation) in Model 2 and Model 5. Lastly, we incorporated all the interaction terms in Models 3 and 6 shown in Table 4. Table 4 also indicates that $R$-square $\left(R^{2}\right)$ increases significantly for both service performance (Model 2 and 3) and service innovativeness (Model 5 and 6), suggesting the significance of the main effects and interaction terms.

The variance in business performance explained by the third model, including the set of control variables and the interaction effects relating $\Delta M S$, explains a significant amount of variance $(F=$ 5.053 , adjusted $\left.R^{2}=0.237, p<.001\right)$. The interaction term virtually replaced the effect of organizational structure on service innovativeness and increased the explanatory power of the model from $47.9 \%$ without the interaction term to $53.4 \%$ with it. As revealed in Table 4 , the sixth model was well significant $\left(F=12.871\right.$, adjusted $\left.R^{2}=.493, p<.001\right)$, showing a significant amount of variance in service innovativeness orientation. As we included the moderating effect in hypothesis 3, two simple slope tests were included to create further insights into the interactive relationships (Aiken \& West, 1991). We set the low/high level of each moderating variable to one standard deviation below/above its mean. Then, we substituted moderators in the equations with the low/high values to attain two simple regression equations for each moderating variable, respectively (see Aiken \& West, 1991; Chen et al., 2014).

$\underline{\text { Table } 4}$

$\mathrm{H}_{1}$ postulates that the higher level of hotel business performance is achieved with the higher the magnitude of service innovativeness. As Model 2 shows, the higher level of service 
innovativeness is positively related to the higher level of hotel business performance ( $\mathrm{B}=.381, \mathrm{p}$ $<.01$ ), in support of $\mathrm{H}_{1} . \mathrm{H}_{2}$ proposes that service innovativeness is primarily the result of organic structure in the hospitality industry. The results of Table 4 show that after controlling for the effects of hotel type, hotel size, ownership, hotel age, brand type, participant's background and years of experience of the respondents, organizational structure has positive and significant association with service innovativeness (Model 5: $\mathrm{B}=.269, \mathrm{p}<.01$ ) in support of $\mathrm{H}_{2}$. This indicates that our assumption, which underlies the positive impact of organizational structure on service innovativeness was confirmed. Although not hypothesized formally, learning orientation $(\mathrm{B}=.351, \mathrm{p}<.001)$, and inter functional coordination $(\mathrm{B}=.241, \mathrm{p}<.01)$, are also found to exert a strong positive impact on predicted service innovativeness (see Model 4). $\mathrm{H}_{3}$ pertains to the interactions between learning orientation and organizational structure. As Table 4 shows, learning orientation strengthens the effect of organizational structure $(B=.259, \mathrm{p}<.01)$. Therefore, $\mathrm{H}_{3}$ is supported. Figure 2, Panel A, indicates that the increase in the levels of foreign learning orientation significantly boosts the effectiveness of organic structure on service innovativeness.

\section{Figure 2 Panel $A$,}

$\mathrm{H}_{4}$ predicts that the inter-functional coordination moderates the relationships between organizational structure and service innovativeness. Table 4 shows that the interaction between inter organic structure and inter functional coordination is positive and significant $(\mathrm{B}=.187, p<$ .01 ), in support of $\mathrm{H}_{4}$. Figure 1, Panel B, depicts that the positive association between organic structure and service innovativeness becomes stronger when all firm's functions make an attempt to cooperate and contribute to disseminate the customers and competitors' information in the hotels. 


\section{Figure 2 Panel B,}

\section{DISCUSSION}

This paper aimed to investigate the influence of organizational structure on service innovativeness. It also tested the moderating roles of learning orientation and inter functional coordination on service innovativeness in order to understand how organic structure influences service innovativeness when it is effectively leveraged with favorable organizational factors. In line with previous research (See Deshpandé et al., 1993; Grissemmann et al., 2013; Tajeddini \& Trueman, 2012), this study showed that there is a positive relationship between service innovativeness and performance of hotels. In particular, the findings of the study reinforce the previous studies who found that innovativeness and new service deployment has a positive impact upon performance such as ROI achievement, sales goal achievement and profit goal achievement (Langerak \& Hultink, 2006; Nakata et al., 2006). Perhaps this is because service innovation leads to perceived opportunities in new horizons of the market, and conversely, broader scope leads to more market exposure and experiences, hence new ideas for effectiveness and efficiency (Miller, 1987).

sThe results are consistent with the prior research conducted in European countries (Tajeddini \& Trueman, 2012) indicating that firms should not miss out on new ideas that might have been generated from customers, employees and competitors. In addition, service innovativeness puts more emphasis on entrepreneurial spirit and activity such as creativity and innovative idea generation (Busenitz et al., 2000). In hotels, service innovativeness sets the tone and orientation

to adopt a more customer oriented approach to offering differentiated services, meeting and exceeding their expectations and delivering value and thus in return enhance the sales and business performance (Grissemmann et al., 2013). 
This study's findings also showed that the organic structure has a positive impact on the service innovativeness. This finding supports the previous research by Horng et al. (2017) and Grissemann et al. (2013) who also found that decentralized organizational structure would stimulate service innovation. It is indeed the case that adopting a service innovative orientation requires reducing the bureaucracy, having open and abundant communication at and between different layers of organizational hierarchy and more importantly making sure that customers' expectations are reflected, understood and responded to efficiently in a timely manner. Flexibility and rapid decision-making through free flow of communication and also empowering front line employees could lead to stronger service innovativeness (Grissemann et al., 2013; Ottenbacher \& Harrington, 2010). Delivering value to customers requires listening and responding to their expectations and needs carefully so this could only be achieved through adopting a decentralized structure and thus enabling the flow of creative and innovative ideas into the hotel organizations' decision-making and implementation mechanisms.

This study's distinctiveness lies within its ability to capture the unique and important interface between service innovativeness, learning orientation and organizational structure. The study findings provide support to the previous literature (Nieves et al., 2014; Tang 2016) that organizational learning is paramount to service innovativeness. However, our study goes beyond the existing literature and also demonstrates that organizational structure has a stronger effect on service innovativeness when learning orientation of hotel organizations is high rather than low. This suggests that adopting a decentralized organizational structure might lead to better service innovativeness. However, it is only through the higher learning orientation, a hotel organization strengthens its ability to generate new and innovative ideas leading to the delivery of value to the customers i.e. speedy service, efficient consumption of products and services, comfort and a 
better consumption experience. A strong learning orientation in hotels requires gathering market intelligence about the customers and competitors (direct and indirect competition) as well as changing political, economic, socio-cultural and technological market trends. A strong willingness and desire to learn about market trends and customer feedback demonstrated in the development and effective use of market intelligence and customer feedback collection and evaluation mechanisms can help hotel organizations absorb the benefits of decentralized organizational structure leading to service innovativeness.

Another distinct contribution of this study is that it demonstrated the important relationship between organizational structure, service innovativeness and inter-functional coordination. Moreover, the findings of this study showed that organizational structure has a stronger effect on service innovativeness when inter functional coordination are high rather than low. Previous research also acknowledges the importance of inter-functional coordination for service innovation (Auh \& Menguc, 2005; Wang, 2014) and more specifically the role of interfunctional coordination in the exploitation of market knowledge and thus developing customer focused innovative product and service ideas in restaurants (Altinay, 2014). This study went beyond the existing literature and showed that inter-functional coordination is essential for the effective utilization of the decentralized organizational structure leading to stronger service innovativeness. Hotel organizations need to encourage the coordination and harnessing of the existing expertise and experience from different functional areas including housekeeping, front office, food and beverage, marketing and human resources for the development of creative and innovative product and service ideas delivering value to the customers. Such an approach will help with the more effective development and sharing of creative ideas in a decentralized organizational environment. As a result, hoteliers are able to leverage the advantages associated 
with harmonizing of diverse resources in different functions of their hotels to generate value for customers.

The results suggest that inter-functional coordination, and learning orientation each individually had positive and significant impact on service innovativeness. This proposes, as inter-functional coordination and learning orientation increase, the effect of organic structure on service innovativeness was positive and significant. Thus, organic structure led to service innovativeness not only directly but also under situations where inter-functional coordination and learning orientation were high. Our simple slope analyses supported this finding; the effect of organic structure on service innovativeness increased as inter-functional coordination and learning orientation increased. From a practical standpoint, this implies that hotels can enhance service innovativeness by developing a forum for exchange and sharing new knowledge, experiences and ideas, resolution of problems, and innovative responsiveness as well as commitment to learning and shared values (Auh \& Menguc, 2005). Thus, the fast dissemination and diffusion of new intelligence to related functions and coordinating the units' synergistic activities is required to foster service innovativeness within an organic structure (Wang, 2014).

\section{CONCLUSION AND IMPLICATIONS}

This paper makes several distinct contributions. Firstly, prior literature in marketing, management and entrepreneurship research domains has suggested that the application of theory from the manufacturing industry in an attempt to explain relationships in service industry is inconsistent and not direct (e.g., Becker, 1995; Crawford-Welch, 1990). Prior research (e.g., Becker,1995; Erramilli \& Rao, 1993), has documented that the service industry including hospitality becomes more idiosyncratic, that it requires specific know-how, professional training 
and skills including specific knowledge development aligned with its distinct and peculiar characteristics. In response to these critiques and calls, this study investigated service innovativeness in hotels in the Japanese hospitality industry. Secondly, this study extended previous literature about service innovation in hotels (Grissemmann et al., 2013; Tajeddini \& Trueman, 2012; Tang, 2016) by demonstrating the complex relationship between service innovativeness, organizational structure, organizational learning and inter-functional coordination. In particular, the study demonstrated the significant role of the learning orientation and inter-functional coordination in leveraging the influence of organizational structure on service innovativeness.

\section{Implications for practice}

The results of this research suggest that if top hotel managers and executives are open to receive new ideas from different sources in order to meet customer needs, they are more likely able to improve business performance in the hospitality industry. Hotel managers need to implement a system that enables customers to provide feedback that can then be used to improve service innovation. This can be conducted through existing feedback forms but also in a more informal manner such as the integration of customer's ideas directly into services when the opportunity arises. Thus, having a more receptive atmosphere for service innovation is important for hotel managers to cultivate with their customers but also within their organizational structure. This involves a more open innovation approach to service innovation, which is increasingly being regarded as important in the interconnected world that places emphasis on technology devices between customers and hotels being integrated in a more seamless manner. Therefore, our results imply that hotel managers should be aware of how improving service innovativeness (e.g., 
openness to new ideas, tendency to receive new ideas from internal/external people) enhances effectiveness measures e.g. exceeding market share/profit/sales growth objectives, and has a strong positive effect on efficiency measures such as profitability, ROI and ROS goals thus giving the hotel an critical competitive advantage. As there is more competition between traditional hotels and more innovative service providers such as Airbnb placing an emphasis on customer receptivity to service innovation is important. Arguably, managers are advised to place a high value on new ideas, believe that creative thinking is not bizarre, listen to the ideas and reports regarding costly errors in addition to offering observations about mistakes or questionable decisions. From a practical standpoint, this implies that hotels can enhance service innovativeness by developing a forum for exchange and sharing new knowledge, experiences and ideas, resolution of problems, and innovative responsiveness as well as commitment to learning and shared values. Thus, the fast dissemination and diffusion of new intelligence to related functions and coordinating the units' synergistic activities is required to foster service innovativeness within an organic structure.

To improve the hotel's ability to grow and generate wealth, it is believed that it is essential to introduce a service innovation strategy, which clearly defines the goals and role of service innovation within the hotel business and how it fits with other corporate and business strategies. Furthermore, the strategy should incorporate both planned and emergent service innovation and modification and utilize a product portfolio management system, to ensure that adequate human, material, financial and other necessary resources that are crucial to service innovation are allocated appropriately. The adoption of the strategic bucket system would support resource deployment and ensure that resource allocation is effectively monitored. The main recommendations for hotel managers coming from the findings of this study are as follows. To 
introduce a visible service innovation process, which is guided by the strategic aims and objectives of the service innovation strategy within the corporate and business strategies. The service innovation process would provide a more structured approach to product innovation and enable each stage to be monitored and evaluated in terms of the allocation and performance of human, material and financial resources against clear targets and timescales. The process should spell out the series of interrelated activities and build in the utilization of specialist, crossfunctional knowledge and expertise at all stages. Creating a cross-functional service innovation team, which will enable a closer, more systemic link between the service innovation strategy, the service innovation process and ensure that the utilization of cross-functional knowledge is being managed and monitored. The service innovation team, which could be virtual or co-located, would engender a greater level of cross-functional collaboration, communication and integration of specialist knowledge, roles and ideas across key functional areas, including $R \& D$, marketing, technical and sales teams. The cross-functional service innovation team would enable the fusion of technical, industry-specific and generic operational expertise, in order to bring together knowledge workers, whose specialist roles, knowledge and skills complement each other. Developing a knowledge management strategy for the business. This will enable companies to utilize personalization and codification strategies with processes to capture and disseminate tacit, explicit, specialist and functional knowledge before, during and after service innovation projects. It would also ensure the transfer of knowledge within and across the business entities and reduce the risk of a duplication of effort and increased development costs. Developing and implementing an employee communications strategy, with the HR Manager, aimed at improving levels of communication across the business. This strategy will enable a more coordinated and systemic approach to communication, particularly across the business entities where there is a 
propensity to duplicate service innovation effort due to poor information and knowledge sharing. It will also identify appropriate communication channels and media that are tailored to meet the needs of end users, such as the blog for technical teams. The utilization of internal social media, through enterprise social networks, would provide a contemporary way to engage individuals, who are seasoned social media users. This would also offer a socio-technical aspect to the communication system and satiate knowledge workers' requests for more social interaction with colleagues. To stimulate service innovativeness successfully, top management must demonstrate the willingness to suffer some loss of control, decentralize decision making, give more ownership to their employees encouraging more innovative, opportunity seeking and entrepreneurial behaviors.

\section{FUTURE RESEARCH SUGGESTIONS}

Based on the findings of this research, more work is needed on replicating our study on the role of organizational structure and service innovativeness in hotels to see how changing forms of innovation such as open innovation are being implemented in the hotel industry. This could include focusing on research avenues addressing different types of service innovativeness based on cultural beliefs in terms of how feedback is received and acted upon by hotel managers. Another suggestion would be for more research to look into how learning and inter-functional coordination differs based on the service experience of customers in a hotel. This paper has extended the literature in this regard but more work is needed to see how hotel structures are changing based on technological change and competitiveness.

As discussed in this paper there is an interesting emerging research stream about collaboration and service innovation based on organizational culture that needs to be continued in order to understand the complexities and connections between these areas. Instead of just relying on paid 
employees, more research is needed on understanding the co-creation process between all

stakeholders in the service experience at hotels. This could involve extending the research in this

paper to focus more on competition based on inter-functional collaboration in hotels based on

geographic location. A limitation of this paper is the generalizability due to the unique

characteristics of the Japanese hotel industry so more research should focus on service

innovation in hotels compared to other service providers such as restaurants.

\section{REFERENCES}

Aas, T. H., Breunig, K. J., Hydle, K. M. and Pedersen, P. E., (2015). "Innovation Management Practices In Production-intensive Service Firms." International Journal of Innovation Management 19(5): 1-27.

Agarwal, S., Erramilli, M. K.,\& Dev, C. S. (2003). "Market orientation and performance in service firms: role of innovation." The Journal of Services Marketing 17(1): 68-82.

Ahearne, M., Lam, S. K., Mathieu, J., E., \& Bolander, W., (2010). "Why Are Some Salespeople Better at Adapting to Organizational Change?" Journal of Marketing 74(May): 65-79.

Aiken, L. S., and West, S.G., (1991). Multiple Regression: Testing and Interpreting Interactions. Newbury Park, CA, SAGE Publications.

Aiken, M., Bacharach, S. B., and French, J. L., (1980). "Organization Structure, Work Process, and Proposal Making in Administrative Beureaucracies." Academy of Management Journal 23(4): 631-652.

Altinay, L. (2009). "Market orientation of small ethnic minority-owned hospitality firms." International Journal of Hospitality Management 29(1): 148-156.

Altinay, L. (2010). "Market orientation of small ethnic minority-owned hospitality firms." International Journal of Hospitality Management 29: 148-156.

Altinay, L., \& Altinay, E., (2006). "Determinants of ethnic minority entrepreneurial growth in the catering sector." The Service Industries Journal 26(2): 203-221.

Altinay, L., and Altinay, M., (2004). "The influence of organisational structure on entrepreneurial orientation and expansion performance." International Journal of Contemporary Hospitality Management 16(6): 334-344.

Anderson, J. C., \& Gerbing, D. W., (1982). "Some methods for respecifying measurement models to obtain unidimensional construct measurement." Journal of Marketing Research 19: 453-460.

Armstrong, J. S., and Overton, T.S. (1977). "Estimating non-response bias in mail surveys." Journal of Marketing Research 14: 396-402.

Auh, S., and Menguc, B. (2005). "Top Management Team Diversity and Innovativeness: The Moderating Role of Interfunctional Coordination." Industrial Marketing Management 34(3): 249-261.

Bagozzi, R. P., \& Phillips, L. W. (1982). "Representing and testing organizational theories: A holistic construal." Administrative Science Quarterly 27: 459-489.

Bagozzi, R. P., and Yi, Y. (1988). "On the Evaluation of Structural Equation Models." Journal of the Academy of Marketing Science 16(1): 74-94.

Baker, W., and Sinkula, J. M. (1999). "The Synergistic Effect of Market Orientation and Learning Orientation on Organizational Performance." Journal of the Academy of Marketing Science 27(4): 411-427.

Becker, C. (1995). "Exploring the relationship between heterogeneity and generic management trends in hospitality organizations." Int. J. Hospitality Management 14(1): 39-52.

Belsley, D. A., Kuh, E., \& Welsch, R.E., (1980). Regression Diagnostics. Identifying Influential Data and Sources of Collinearity. New York, John Wiley \& Sons. .

Bentler, P. M., and Chou, C. P. (1987). "Practical issues in structural modeling." Sociological Methods and Research 16(1): 78-117. 
Binder, P., Kessler, A., Mair, M. \& Stummer, K., (2016). "Organizational innovativeness and its results: a qualitative analysis of SME hotels in Vienna." Journal of Hospitality \& Tourism Research 40(3): 339-363.

Bonner, J. M., \& Walker, O. C., (2004). "Selecting influential business-to business customers in new product development: relational embeddedness and knowledge heterogeneity considerations." Journal of Product Innovation Management 21(3): 155-169.

Borooah, V. A. (1999). "The supply of hotel rooms in Queensland, Australia." Annals of Tourism Research 26(4): 985-1003.

Brettel, M., Chomik, C., and Flatten, T. C., (2015). "How Organizational Culture Influences Innovativeness, Proactiveness, and Risk-Taking: Fostering Entrepreneurial Orientation in SMEs." Journal of Small Business Management 53(4): 868-885.

Browne, M. W., and Cudeck, R. (1993). Alternative ways of assessing model fit. Testing structural equation models. K. A. Bollen, and Longeds, J.S.,. CA., Sage Publications.

Burgess, C. (2013). "Factors influencing middle managers' ability to contribute to corporate entrepreneurship." International Journal of Hospitality Management 32: 193-201.

Burns, T., and Stalker, G.M. (1961). The Management of Innovation. London, Tavistock.

Busenitz, L. W., Gomez, C., and Spencer, J.W. (2000). "Country institutional profiles: Interlocking entrepreneurial phenomena." Academy of Management Journal 43(X): 994-1003.

Campbell, D. T., \& Fiske, D. W. (1959). "Convergent and discriminant validation by the multitraitmultimethod matrix." Psychological Bulletin 56(X): 81-105.

Campo, S., Díaz, A. M., and Yagüe, M. J., (2014). "Hotel innovation and performance in times of crisis." International Journal of Contemporary Hospitality Management 26(8): 1292-1311.

Celucha, K. G., Kasouf, C. J., \& Peruvemba, V., (2002). "The effects of perceived market and learning orientation on assessed organizational capabilities." Industrial Marketing Management 31: 545-554.

Chandler, A. D. (1962). Strategy and Structure. Cambridge, MA., MIT Press.

Chandy, R. K. (2003). "Research as Innovation: Rewards, Perils, and Guideposts for Research and Reviews in Marketing." Journal of the Academy of Marketing Science 31(3): 351-355.

Chang, S.-J., Witteloostuijn,A., V., Eden, L (2010). "From the editors: Common method variance in international business research." Journal of International Business Studies 41(2): 178-184.

Chang, S., Gong, Y., \& Shum, C., (2011). "Promoting innovation in hospitality companies through human resource management practices." International Journal of Hospitality Management 30: 812-818. .

Chen, Y., Tang, G., Jin, J., Xie, Q., \& Li, J., (2014). "CEOs' Transformational Leadership and Product Innovation Performance: The Roles of Corporate Entrepreneurship and Technology Orientation." Journal of Product Innovation Management 31(S1): 2-17.

Child, J., \& Tse, D.K., (2001). "China's transition and its impact on international business." Journal of International Business Studies 32(1): 8-21.

Cohen, J., Cohen, P., West, S.G., Aiken, L.S., (2003). Applied Multiple Regression/Correlation Analysis for the Behavioral Sciences,3rd edn Mahwah, NJ.,, Erlbaum, .

Collis, D. J. (1994). "Research note: how valuable are organizational capabilities." Strategic Management Journal 15(x): 143-152.

Connor, T. (2007). "A consideration of strategic assets and the organizational sources of competitiveness." $\underline{\text { Strategic }}$ Change 16(3): 127-136.

Covin, J., G., and Slevin, D. P. (1988). "The influence of organization structure on the utility of an entrepreneurial top management style." Journal of Management Studies 25(3): 217-234.

Crawford- Welch, S. (1990). An Empirical Examination of Mature Service Environments and High Performance Strategies within those Environments: The Case of the Lodging and Restaurant Industries. Blacksburg, VA., Virginia Polytechnic Institute and State University.

Davis, R., Watson, P., and Man, C.L. (2007). Knowledge management for the quantity surveying profession. Hong Kong SAR, TS 4E - e-Learning and Knowledge Management.

Day, G. S. (1994). "The capabilities of market-driven organizations." Journal of Marketing 58(October): $37-52$.

de Jong, J. P. J. and P. A. M. Vermeulen (2003). "Organizing successful new service development: a literature review." Management Decision 41(9): 844 - 858

Defee, C. C., \& Stank, T. P., (2005). "Applying the strategy- structure- performance paradigm to the supply chain environment." The International Journal of Logistics Management 16(1): 28 - 50.

Deng, S., \& Dart, J., (1994). "Measuring market orientation: a multi-factor, multi-item approach." Journal of Marketing Management 10(8): 725-742. 
Deshpandé, R., Farley, J.U., Webster, F.E. (1993). "Corporate culture, customer orientation, and innovativeness in Japanese firms: a quadrad analysis." Journal of Marketing 57(1): 23-37.

Duncan, R. B. a. W., A. (1978). Organisational learning: implications for organizational design. Research in Organisational Behavior. B. Staw. Greenwich, CT., JAI Press: 75-123.

Erramilli, K., \& Rao, C. P. (1993). "Service firms' international entry-mode choice: A modified transaction- cost analysis approach." Journal of Marketing 57(3): 19-38.

Farsani, N. T., Sadeghi, R., Shafiei, Z., and Shahzamani Sichani, A., (2016). "Measurement of Satisfaction with ICT Services Implementation and Innovation in Restaurants (Case Study: Isfahan, Iran)." Journal of Travel \& Tourism Marketing 33(2): 250-262.

Fornell, C., and Larcker, D. (1981). "Evaluating Structural Equation Models with Unobservable Variables and Measurement Error." Journal of Marketing Research 19: 39-50.

Freeman, J., \& Engel, J. S., (2007). "Models of Innovation: Startups and mature corporations " California Management Review 50(1): 94-119.

García-Villaverde, P., M., Elche, D., Martínez-Pérez, A., and Ruiz-Ortega, M.J., (2017). "Determinants of radical innovation in clustered firms of the hospitality and tourism industry " International Journal of Hospitality Management 61(February): 45-58.

Garcia, R., \& Calantone, R., (2002). "A critical look at technological innovation typology and innovativeness terminology: a literature review." The Journal of Product Innovation Management 19(-): 110—132.

Garvin, D. A. (1993). "Building a learning organisation." Harvard Business Review July-August: 78-91.

Gerbing, D. W., \& Anderson, J. C., (1987). "Improper solutions in the analysis of covariance structures: Their interpretability and a comparison of alternate respecifications." Psychometrika 52: 99-111.

Gerbing, D. W., and Anderson, J.C. (1992). "Monte Carlo evaluations of goodness of fit indices for structural equation models." Sociological Methods \& Research 21: 132-160.

Giri, G. a. T., E.C.-Y. (2006). "Entrepreneurial orientation and the structuring of organizations performance evidence from the Asian hotel industry." International Journal of Contemporary Hospitality Management 18(6): 454-468.

Grissemann, U., Plank, A., and Brunner-Sperdin, A., (2013). "Enhancing business performance of hotels: The role of innovation and customer orientation." International Journal of Hospitality Management 33(X): 347-356.

Hair, J. F., Black, W. C., Babin, B. J., \& Anderson, R. E. (2010). Multivariate data analysis: A global perspective (7th ed.). Upper Saddle River, NJ, Pearson Education, Inc.

Hall, D., J., and Saias, M. A., (1980). "Strategy Follows Structure!" Strategic Management Journal 1(2): 149-163.

Harris, L. C. (2001). "Market orientation and performance: Objective and subjective empirical evidence from UK Companies'." Journal of Management Studies 38(1): 17-43.

Henard, D. H., and Szymanski, D.M., (2001). "Why some new products are more successful than others." Journal of marketing Research 38(3): 362-363.

Hennig-Thurau, T., and Thurau, C., (2003). "Customer Orientation of Service Employees - Toward a Conceptual Framework of a Key Relationship Marketing Construct." Journal of Relationship Marketing 2(1/2): 23-41.

Hirunyawipada, T. B., M. and Blankson, C., (2010). "Cross functional integration as a knowledge transformation mechanism: Implications for new product development." Industrial Marketing Management 39: 650-660.

Ho, C.-H. (2009). "The relationship between knowledge management enablers and performance." Industrial Management and Data Systems 109(1): 98-117.

Hodari, D., Balla, P. J., \& Aroul, R.R., (2017 ). "How Management Structure Affects Hotel Value " Cornell Hospitality Quarterly In Press.

Honma, S., and Hu, J. L., (2012). "Analyzing Japanese hotel efficiency." Tourism and Hospitality Research 12(3): $155-167$.

Horng, J.-S., Liu, C.-H., Chou,S.-F., Tsai, C.-Y., and Chung, Y.-C., (2017). "From innovation to sustainability: Sustainability innovations of eco-friendly hotels in Taiwan." International Journal of Hospitality Management 63(May): 44-52.

Huber, G. P. (1991). "Organizational Learning: The Contributing Processes and the Literatures." Organization Science 2(February): 88-115.

Huber, G. P., and Power, D.J., (1985). "Retrospective Reports of Strategic-Level Managers: Guidelines for Increasing Their Accuracy." Strategic Management Journal 6: 171-180.

Hurley, R. F., and. Hult., G. T. M. (1998). "Innovation, Market Orientation, and Organisational Learning: An Integration and Empirical Examination." Journal of Marketing 62(7): 42-54.

Jacob, M., Florido, C., and Aguiló, E., (2010). "Environmental innovation as a competitiveness 207 factor in the Balearic Islands." Tourism Economics 16(3): 755-764. 
Japan Hotel Almanac (2013) "Directory of Hotels in Japan." Ota Publications.

Javalgi, R. G., Hall, K. D., \& Cavusgil, T., (2014). "Corporate entrepreneurship, customer-oriented selling, absorptive capacity, and international sales performance in the international B2B setting: Conceptual framework and research propositions." International Business Review 23: 1193-1202.

JETRO (2009) "Japan's Hotel Industry." Industrial Report.

Jobber, D. (1995). Principles and Practice of Marketing. England, McGraw Hill Book Company.

Jogaratnam, G., Tse, E.C.-Y., (2006). "Entrepreneurial Orientation and the Structuring of Organizations: Performance Evidence from the Asian Hotel Industry." International Journal of Contemporary Hospitality Management 18(6): 454-468.

Johne, A., and Storey, C. (1998). "New service development: a review of the literature and annotated bibliography." European Journal of Marketing 32(3/4): 184-251.

Kennedy, K. N., Goolsby, J. R., and Arnould, E. J., (2003). "Implementing a Customer Orientation: Extension of Theory and Application." Journal of Marketing 67(3): 67-81.

Khandwalla, P. N. (1977). The Design of Organizations. New York: Harcourt Brace Jovanovich. New York, Harcourt Brace Jovanovich.

Kirca, A. H., Jayachandran, S., and Bearden, W. O. (2005). "Market orientation: A meta-analytic review and assessment of its antecedents and impact on performance." Journal of Marketing 69(2): 24-41.

Lafferty, B. A., and Hult, G. T. M. (2001). "A synthesis of contemporary market orientation perspectives." European Journal of Marketing 35(1): 92-109.

Langerak, F., and Hultink, E. J., (2006 ). "The Impact of Product Innovativeness on the Link between Development Speed and New Product Profitability." Journal of Product Innovation Management 23: 203-214.

Lee, R. P., Ginn, G.O., \& Naylor, G., (2009). "The impact of network and environmental factors on service innovativeness." Journal of Services Marketing 23(6): 397-406.

Lin, X., and Germain, R. (2003). "Organizational structure, context, customer orientation, and performance: Lessons from Chinese state-owned enterprise." Strategic Management Journal 24(11): 1131-1151.

Liu, S. S., Luo, X., Shi, Y. Z. (2003). "Market-oriented organizations in an emerging economy A study of missing links." Journal of Business Research 56(6): 481- 491.

Lyon, D., Lumpkin, G., and Dess, G., (2000). "Enhancing Entrepreneurial Orientation Research: Operationalizing and Measuring a Key Strategic Decision Making Process." Journal of Management 26(5): 1055-1085.

MacInnis, D. J. (2005). "Them vs. Us: Woes on the Bifurcation of the Academic Marketing Discipline." Journal of Marketing 69(October): 14-16.

McKee, D. O., Varadarajan, P., and Pride, W. M., (1989). "Strategic Adaptability and Firm Performance: A Market-Contingent Perspective." Journal of Marketing 53(July): 21-35.

Miller, D. (1987). "Strategy making and structure: Analysis and implications for performance." Acad. Management Journal 30: 7-32.

Nakata, C., Im, S., Park, H. and Ha, Y.-W. (2006). "Antecedents and consequence of Korean and Japanese new product advantage." Journal of Business Research 59(1): 28-36.

Naman, J. L., \& Slevin, D. P., (1993). "Entrepreneurship and the concept of fit: A model and empirical tests." Strategic Management Journal 14: 137-154.

Narver, J. C. a. S., S. F. (1990). "The Effect of a Market Orientation on Business Profitability." Journal of Marketing 54(4): 20-35.

Nicolau, J. L., and Santa-María, M. J., (2013). "The effect of innovation on hotel market value." International Journal of Hospitality Management 32: 71-79.

Nieves, J., Quintana, A., and Osorio, J., (2014). "Knowledge-based resources and innovation in the hotel industry." International Journal of Hospitality Management 38(April): 65-73.

OECD Tourism Trends and Policies (2015). OECD Tourism Trends and Policies 2014. OECD Publishing.: 222227.

Øgaarda, T., Marnburga, E., \& Larsen, S., (2008). "Perceptions of organizational structure in the hospitality industry: Consequences for commitment, job satisfaction and perceived performance." Tourism Management 29: 661-671.

Olson, E. M., Walker, O.C. and Ruekert, R. W., (1995). "Organizing for Effective New Product Development: The Moderating Role of Product Innovativeness." Jourrml of Marketing 59(January): 48-62.

Orfila-Sintesb, F., and Mattsson, J., (2009). "Innovation behavior in the hotel industry." Omega 37(X): 380-394.

Ottenbacher, M., and. Gnoth., J. (2005). "How to develop successful hospitality innovation." Cornell Hotel and Restaurant Administration Quarterly 46(2): 205-222. 
Ottenbacher, M., C., \& Harrington, R., J., (2010). "Strategies for achieving success for innovative versus incremental new services." Journal of Services Marketing 24(1): 3-15.

Ottenbacher, M., Shaw, V., and Lockwood, A., (2006). "An Investigation of the Factors Affecting Innovation Performance in Chain and Independent Hotels." Journal of Quality Assurance in Hospitality \& Tourism 6(3-4): 113-128.

Pattit, J. M., and Wilemon, D. (2005). "Creating high-performing software development teams." R\&D Management 35(4): 375-393.

Podsakoff, P. M., and Organ, D. W. (1986). "Self-reports in organizational research: Problems and prospects." Journal of Management 12(2): 531-544.

Podsakoff, P. M., MacKenzie, S. B., Lee, J.-Y., \& Podsakoff, N. P. (2003). "Common method biases in behavioral research: A critical review of the literature and recommended remedies." Journal of Applied Psychology 88(X): 879-903.

Randhawa, P., Kim, M., Voorhees, C. M., Cichy, R. F., Koenigsfeld, J. P. and Perdue, J. (2015). "Hospitality Service Innovations in Private Clubs." Cornell Hospitality Quarterly 57(1): 93-110.

Richardson, G. B. (1972). "The Organisat ion of Industry." The Economic Journal 82(327): 883-896.

Robbins, S. P., De Cenzo, D. A., \& Coulter, M., (2013). Fundamentals of Management, Pearson, Prentice Hall.

Robbins, S. R., and Judge, T. A., (2013). Organizational Behavior. Prentice Hall, 15/E, Pearson.

Robson, S., and Achur, J. (2012). First findings from the UK Innovation survey 2011. Innovation Skills. Great Britain, Department for Business.

Roth, H., and Fishbin, M., (2015) "Global hospitality insights': Ernst \& Young Available at: http://www.ey.com/Publication/vwLUAssets/ey-global-hospitality-insights- $\quad$ 2015/\$File/ey-globalhospitality-insights-2015.pdf (Accessed: 12 December 2015).".

Rouziès, D., Anderson, E., Kohli, A. K., Michaels, R. E., Weitz, B. A., and Zoltners, A. A., (2005). "Sales and marketing integration: a proposed framework." Journal of Personal Selling \& Sales Management XXV(2 (spring)): 113-122.

Ruekert, R. W. (1992). "Developing a market orientation: an organizational strategy perspective." International Journal of Research in Marketing 9: 225-245.

Sawayanagi, T., Sorgiovani, F., \& Ping, S. Y., (2014). Tokyo 2020 Olympics: Expectations for the Hotel Industry. November. J. Hotels \& Hospitality Group. Tokyo, JIL Hotels \& Hospitality Group.

Sin, L. Y. M., Tse, A.C.B., Heung, V. C.S., and Yim, F.H.K. (2005). "An analysis of the relationship between market orientation and business performance in the hotel industry." International Journal of Hospitality Management 24 555-577.

Sinkula, J., Baker, W., and Noordewier, T. (1997). "A Framework for Market-based Organizational Learning: Linking Values, Knowledge, and Behavior." Journal of the Academy of Marketing Science 25(4): 305-318.

Sinkula, J. M. (1994). "Market information processing and organizational learning." Journal of Marketing 58(1): 35 45.

Slater, S., and Narver, J.C. (1995). "Market orientation and the learning organization." Journal of Marketing 59(3): 63-74.

Stonehouse, G. H., and Pemberton, J.D., (1999). "Learning and knowledge management in the intelligent organisation." Participation and Empowerment: An International Journal 7(5): 131-144.

Subramanian, A., \& Nilakanta, S., (1996). "Organizational innovativeness: exploring the relationship between organizational determinants of innovation, types of innovations, and measures of organizational performance " Omega, International Journal of Management Science 24(6): 631-647.

Tajeddini, K. (2010). "Effect of Customer Orientation and Entrepreneurial Orientation on Innovativeness: Evidence from the Hotel Industry in Switzerland." Tourism Management 31(2): 221-231.

Tajeddini, K. (2011). "Customer Orientation, Learning Orientation, and New Service Development: An Empirical Investigation of Swiss Hotel Industry." Journal of Hospitality \& Tourism Research 35 (4): 437 - 468.

Tajeddini, K., \& Trueman, M, (2012). "Managing Swiss Hospitality: How cultural antecedents of innovation and customer-oriented value systems can influence performance in the hotel industry." International Journal of Hospitality Management 31(4): 1119-1129.

Takeuchi, K. (2010). "Overview of the Japan hotel market." NLI Research Institute May: 1-13.

Tang, T.-W. (2016). "Making innovation happen through building social capital and scanning environment." International Journal of Hospitality Management 56(July): 56-65.

Theriou, N., Maditinos, D., \& Theriou, G., (2011). "Knowledge Management Enabler Factors and Firm Performance: An Empirical Research of the Greek Medium and Large Firms." European Research Studies Journal 14(2): 97-134. 
Thompson, V. A. (1965). "Bureaucracy and Innovation." Administrative Science Quarterly 10(5): 1-20.

Trueman, M., and Jobber, D., (1995). "Designing the front end: how attitudes towards new products are related to company performance." World Class Design to Manufacture 2(1): 17-24.

Tsai, C., Horng, J, Liu, C \& Hu, D., (2015). "Work environment and atmosphere: the role of organizational support in the creativity performance of tourism and hospitality organizations." International Journal of Hospitality Management 46: $26-35$.

Tsai, K.-H., \& Yang, S. Y., (2014). "The contingent value of firm innovativeness for business performance under environmental turbulence." International Entreprenurship Management Journal 10(2): 343-366.

Tsai, K. H., Liao, Y., C., \& Hsu, T.T,. (2015). "Does the use of knowledge integration mechanisms enhance product innovativeness?" Industrial Marketing Management 46: 214-223.

Tyler, B. B., and Gnyawali, D. R., (2002). "Mapping managers' market orientations regarding new product success." Journal of Product Innovation Management 19: 259-276.

van Ark, B., Broersma, L. and den Hertog, P., (2003). Services Innovation, Performance and Policy: A Review. The Hague: Ministry of Economic Affairs.

Venkatraman, N. (1989). "Strategic orientation of business enterprises: the construct, dimensionality, and measurement." Management Science 35(8): 42-62.

Wang, C.-H. (2014). "Does Service Innovation Matter in High-Tech Industry?" Journal of Technology Management Innovation 4(9): 42-55.

Wang, C. A., L., (2012). "Social embeddedness, entrepreneurial orientation and firm growth in ethnic minority small businesses in the UK." International Small Business Journal 30(1): 3-23. .

Wooldridge, B. R., and Minsky, B. D., (2002). "The Role of Climate and Socialisation in Developing Interfunctional Coordination." The Learning Organisation 9(1): 29-38.

World Travel and Tourism Council (2014) "Economic Impact Research. Available at: http://www.wttc.org/research/economic-impact-research/ (Accessed: 5 January 2014).".

Ye, J., Marinova, D., and Singh, J., (2007). "Strategic Change Implementation and Performance Loss in the Front Lines." Journal of Marketing 71(October): 156-171.

Yeh, Y. J., Lai, S.Q., and Ho, C.T., (2006). "Knowledge management enablers: A case study." Industrial Management and Data Systems 106(6): 793-810.

Zolfagharian, M., \& Paswan, A., (2008). "Do consumers discern innovations in service elements?" Journal of Services Marketing 22(5): 338-352. 